Journal of Southeast Asian

Volume 10

Issue 2 [Special Issue] Forty and Forward:

Research on the New Second Generation of

Article 6

Southeast Asian American Students

2015

\title{
Making My Path by Walking: Using Community Based Participatory Research in Vietnamese American Studies
}

Loan T. Dao

U. Mass. Boston, Itd2@stmarys-ca.edu

Forty and Forward: Research on the New Second Generation of Southeast Asian American Students

Vichet Chhuon

University of Minnesota

anthony lising antonio

Stanford University

Follow this and additional works at: https://docs.lib.purdue.edu/jsaaea

\section{Recommended Citation}

Dao, Loan T. (2015) "Making My Path by Walking: Using Community Based Participatory Research in Vietnamese American Studies," Journal of Southeast Asian American Education and Advancement. Vol. 10 : Iss. 2, Article 6.

DOI: $10.7771 / 2153-8999.1134$

Available at: https://docs.lib.purdue.edu/jsaaea/vol10/iss2/6

This document has been made available through Purdue e-Pubs, a service of the Purdue University Libraries. Please contact epubs@purdue.edu for additional information.

This is an Open Access journal. This means that it uses a funding model that does not charge readers or their institutions for access. Readers may freely read, download, copy, distribute, print, search, or link to the full texts of articles. This journal is covered under the CC BY-NC-ND license. 


\title{
JSAAEA Journal of Southeast Asían American
Education and Advancement
}

Vol. 10 Iss. 2 Special Issue (2015)

WWW.JSAAEA.org

\section{Making My Path by Walking: Using Community Based Participatory Research in Vietnamese American Studies}

\author{
Loan Thi Dao \\ University of Massachusetts Boston
}

\begin{abstract}
This paper outlines my Community-Based Participatory Research (CBPR) process as a pedagogical pathway: the creation of community-based curricula, of developing relationships with community partners, and the complexities I grappled with as a new Vietnamese American scholar at a university next to a large co-ethnic enclave. Specifically, I reflect on the partnership between my Vietnamese American Studies courses and a local elementary school with a high percentage of newly immigrated students from Viet Nam. We engaged in oral history interviews, classroom visits, the production of bilingual children's books, and English language tutoring to build inter-generational bridges. Through this reflective process, I consider the role of the university in providing added support for Sheltered English Immersion (SEI) teachers as sources of cultural enrichment, community development and engagement, and pipelines for first-generation college students. I discuss the challenges and successes of developing a new community partnership with a local elementary school (pseudonym Hope Elementary) and building bridges between second-generation immigrant college students and first generation immigrant community members. The CBPR process offers an opportunity to begin a dialogue about the trajectory for teaching in and with transnational communities. In particular, it offers avenues of teaching and scholarship with Southeast Asian American communities that are relevant to their contemporary lived experiences.
\end{abstract}

\section{Introduction}

As refugees from Viet Nam, Laos, and Cambodia enter forty years of resettlement in the United States, the question of our temporal and spatial location has become prevalent in pedagogical and curricular discussions within the field of Southeast Asian American Studies. Since the emergence of the field, historical analyses of war and early refugee resettlement has occupied scholarly, cultural, and curricular priorities. While there have been innovative contributions to

\footnotetext{
@

SORERIIEHISRESERNED Readers are free to copy, display, and distribute this article, as long as the work is attributed to the author(s) and the Journal of Southeast Asian American Education \& Advancement, it is distributed for non-commercial purposes only, and no alteration or transformation is made in the work. More details of this Creative Commons license are available at http://creativecommons.org/licenses/by-nc-nd/3.0/. All other uses must be approved by the author(s) or JSAAEA.

Journal of Southeast Asian American Education \& Advancement, Vol. 10 Iss. 2 Special Issue (2015)
}

ISSN: 2153-8999 
the field in the past decade, the tendency of scholars in the field has been to either locate themselves within this historical dialogue or move squarely away from it. I suggest that as new generations of Southeast Asian and Southeast Asian American students enter college classrooms, without rejecting the historical influences that inform current circumstances, new curricula should (re)engage with the current shifts, needs, and priorities of local and transnational communities, thus staying relevant to the contemporary lives of students that speak to the continual migration and movement patterns within this population. In doing so, developing pedagogical practices using community-based participatory practices can build and provide opportunities for student not only to provide leadership and service-learning opportunities within this under-served student demographic, but also develop critical new research and knowledge production that is relevant to community stakeholders.

\section{Background}

According to the Southeast Asian Resource Action Center (SEARAC, 2011), the population of Vietnamese in the United States has continued to evolve since its first major immigration cohort in 1975. In the 2010 Census, an estimated $24.1 \%$ of the 1,799,632 Vietnamese in the United States are of college age, between 18-34 years (p. 6). Approximately 856,059 are foreign-born and naturalized U.S. citizens, while 305,051 are estimated to be foreign-born and not U.S. citizens (p. 9). Given this, 15\% of the population speaks "English Only," and 51.5\% speak English "less than very well" (p. 11). Census numbers also report 15.2\% of Vietnamese living at or below the Federal Poverty Level (p. 13). These statistics are consistent with the demographics of the Vietnamese in the SEI classrooms with which I partner. However, 36\% of the Vietnamese American population is US-born, representative of the changing demographics within many college classrooms nationally. Understanding the differences within this student population and their ethnic communities is critical to creating the most effective pedagogy and curricula to meet student needs (Chung, 1999).

In the state of Massachusetts, there are 47,636 Vietnamese Americans, a 30\% increase since 2000. 11,670 Vietnamese Americans live in Boston, with 70.4\% foreign-born, and 27.6\% of this percentage arrived after 2000. Consequently, a large majority, 67.2\%, reports that they speak English "less than very well." The median income is \$32,969 for Vietnamese Americans in this state, and the per capita income equals $\$ 14,268$. The income brackets translate into relatively high poverty rates at $32.8 \%$ for families and $36.3 \%$ for individuals (Lo \& Tran, 2012, p. 6-7). In Dorchester, the general population is 31,785 , with $13.3 \%(4,231)$ identifying as "Asian," the majority being Vietnamese (BRA, 2012, p. 29-30). In the Boston Public Schools (BPS), native Vietnamese speakers at the elementary level are the third largest Limited English Proficient (LEP) student population, behind Spanish and Chinese speakers, 8.0\% of 19,708 enrolled in pre-Kindergarten through $3^{\text {rd }}$ grade (Uriarte \& Karp, 2009, p. 6). At Hope Elementary, there are 127 students enrolled in the Vietnamese SEI courses between Prekindergarten and fifth grade, and of that total 105 are documented as low-income based on their enrollment in food assistance programs (Hope Elementary School records 2014-2015).

\section{Sheltered English Immersion}

As Massachusetts gradually became a site of immigration in the 1980s-1990s, the enrollment for bilingual courses increased as well. By the mid-1990s, "English Only" initiatives began to spread 
into states that had high English Language Learner (ELL) populations, particularly within the public school systems. Massachusetts passed a referendum in 2002 that ended Transitional Bilingual Education (TBE) and replaced it with Sheltered English Immersion (SEI). At the same time, the No Child Left Behind Act of 2001 created a high stakes testing system that was required for advancement and graduation, which raised the importance of the Massachusetts Comprehensive Assessment System (MCAS) that had been in place since 1993 (Kiang, 2006, p. 106). LEP students were also required to take these tests beginning in Grade 3 (Uriarte \& Karp, 2009, p. 18). As a result, "during the three years after [the Referendum] implementation and MCAS as a high-stakes accountability test, LEP identification, program participation, and outcomes plummeted" (Tung et al., 2009, p. 15).

\section{University of Massachusetts Boston (UMB)}

The University of Massachusetts Boston is the only public four-year institution in the city of Boston. Its fifty-year history has been committed to an urban mission serving local, commuter students throughout metropolitan Boston and its surrounding cities. UMB has a student population of approximately 17,000 that is embedded in local working-class communities who have lived there for generations as well as new immigrant populations. The average household income for UMB students' parents tends to be less than at other public universities, with $11 \%$ reporting less than $\$ 20,000 /$ year, $16 \%$ reporting $\$ 20,000-39,000 /$ year, and $18 \%$ reporting $\$ 40,000-59,000 /$ year (UMB Office of Institutional Research, 2007). There are 60\% firstgeneration college students, $46 \%$ who identify with a racial minority group, $40 \%$ first-generation immigrant and refugee students and speak a language other than English at home (UMB Office of Institutional Research, 2013 \& 2014). It also has the largest population veteran students of any four-year institution in Boston. UMB has a nationally recognized Carnegie Community Engagement Classification for its outstanding commitment to community-engagement, with 938 community-engage programs and 1,975 community partners (Office of Community Partnerships, UMB). The university is located in Dorchester, next to the largest Vietnamese American community in the state and the tenth largest nationally (BPSOS, 2012). The majority of Vietnamese American students at UMB come from Dorchester, and either grew up in or in the surrounding area, or have relatives who live here. The students vary from 1.5-second-generation immigrants, who either immigrated as adolescents or were born here to first-1.5 generation immigrant parents. The international student population from Viet Nam is the third largest at the university, and every semester, one or two international students enroll in my Vietnamese American Studies courses. Overall, the students have an inherent operating knowledge of the enclave, but they have never been asked intellectualize or critically analyze their social environment. The majority have stated feeling insecure about their knowledge of Vietnamese American communities and culture because of their limited Vietnamese proficiency, and thus they tend enroll in the Vietnamese language courses along with my courses.

\section{Method}

\section{Participants}

This qualitative study is based on my reflection as a practitioner teaching Vietnamese American Studies courses over the course of four academic semesters, between the fall of 2011 and the 
spring of 2015. I taught Vietnamese American Studies courses once a year between 2011-2013, and then successive semesters between spring 2014 and spring 2015. A total of forty-six students participated in community-engaged projects through these courses, with twenty students participating specifically on the projects with the local elementary school. Six of the twenty students participated in this partnership for more than one academic semester. The students ranged in age from 18-25 years, undergraduate freshmen-seniors. The partnering school has six SEI Vietnamese-speaking teachers and SEI classes from pre-Kindergarten through fifth grade, with fourth and fifth grade combined. Participants were informed that their evaluations, projects, and reflections could be used in future publications, with aliases attached to them to secure anonymity. The main units of analysis in my study are the college students in my courses, and the secondary subjects are the institutions and Hope Elementary Vietnamese Language SEI teachers and students. While Hope Elementary parents and students play a role in understanding the process of developing the CBPR projects, the focus of this study is on the experiences of the college students and the forging of campus-community partnerships.

\section{Data Collection}

My data is based on my personal field notes and journal entries of my courses, classroom visits to Hope Elementary, interactions with teachers, and parents and Hope Elementary students. I also collected student course evaluations, required reflections of their experiences in the projects, observations of their participation, debrief meetings to reflection on their roles in the projects, informal conversations with students outside of class, and the products they created as course requirements. These products include oral history interviews, community questionnaires, interviews with Hope Elementary and UMB alumni, bilingual children's books, lesson plans for the tutoring sessions, and end of the semester reflection papers.

\section{Data Analysis}

My data analysis is drawn from grounded theory approaches from both Anselm L. Strauss (1987) at the University of Chicago and Barney G. Glaser at Columbia University (1978), which, "simply stated, grounded theory methods consist of systematic, yet flexible guidelines for collecting and analyzing qualitative data to construct theories "grounded in the data themselves" (Charmaz, 2006, p. 2). I collected rich data with "thick" descriptions in my field notes, student assignments, reflections, and products. From the data gathered, I created identification numbers and aliases for all subjects. I followed grounded theory methods to allow for themes to emerge from the data organically (Charmaz, 2006) by using in vivo for initial coding and axial as my focused coding method to develop main points for narrative development and theoretical analysis (Strauss \& Corbin, 1998). The process of combining these primary source materials in the context of secondary academic sources allowed me to engage in what grounded theorists identify as "reconstructing theory" (Glasser \& Strauss, 1967; Strauss \& Corbin, 1990; Charmaz, 2006). Finally, in my process, students in my Vietnamese American Studies course in the spring of 2014 engaged in collective coding processes after conducting individual interviews with Hope Elementary/UMB alumni. This method set the foundation for them to storyboard their bilingual children's books (one of the class products). 


\section{Theoretical Framework}

\section{Service-Learning and Civic Engagement}

In recent years, "service-learning" has become a popular term in university curricular development, but the term has been used broadly with much variance in meaning, criteria, and outcomes. John Saltmarsh and Edward Zlotkowski (2011) offer a new way to approach civic engaged education through service-learning models in higher education. They suggested that faculty must first challenge their assumptions about the academic institution. While most institutions continue to perpetuate a professional culture detached from the "subjectivity" of embedding oneself within a community, through the rewards system of what constitutes an "authentic academic," Saltmarsh and Zlotkowski argue that it embodies an inherent contradiction to the growing trend of "service-learning" and "civic engaged" learning in core curricular mandates by university administrations that see the role of faculty as integrating their teaching, service, and research. They suggest, "Faculty scholarship is integrated across faculty roles as they embrace connections and collaborations across disciplines, between the curriculum and the co-curriculum, and across the boundaries of the campus and the community" (2010). Additionally, learning outcomes need to return to the original mission of the academe whereby curricula focuses on teaching "critical thinking, problem-solving, moral reasoning, commitment to democratic values and civic participation, intercultural understanding, responsibilities in a global society, and social agency - translating knowledge into action" (Ibid.). The critical component to the success of faculty roles and student-learning outcomes must come from the university administration, which encourages and rewards the integration of community-campus reciprocal partnerships in research, service, and teaching in addition to creating a learnercentered and resource-rich environment for such endeavors to be successful.

If scholars are to commit to the prioritization of community and civically minded curricula, and not simply "attach" it to current institutional structures, then the academic community must rethink their understanding of knowledge production, faculty roles and research, and how it measures student-learning outcomes. In order to meet the changing lived experiences of voluntary and involuntary migration of millennial students, there must be an integration of transnational communities and identity formation based on the web of these relationships through flexible and evolving pedagogies.

\section{Community-Based Participatory Research (CBPR)}

Serving a community through research and teaching involves the prioritizing of community agendas and needs as a way of framing the direction of research. In short, it begins with the research question and then includes making the research process accessible to those outside of the university and as equitable partners from inception to analysis to dissemination (Israel et al., 1998; Israel et al., 2003; Minkler, 2005; Minkler \& Wallerstein, 2008). According to Peter Park (1993), CBPR is the framework for the realization of self-determination and social transformation in its process of research inquiry, knowledge production, and its use of that knowledge to address community issues through collective action to impact policy or structural changes (p. 3). As a tool of popular education, CBPR involves research based on "living knowledge" that "captures the ideal of goal-oriented experiential learning, and transformative 
pedagogy (Dewey, 1997; Freire, 1970)" (p. 3). The researcher helps facilitate the process whereby participants identify the problem and a process of collective investigation. In using a problem-solving approach to engage both students and community partners, students are not seen as "empty vessels" to be filled with pre-existing knowledge, but instead as social actors who bring organic knowledge relevant to the course (Arnold \& Burke, 1983). Moreover, this approach offers the opportunity for students and/or community members who are the subjects of research to define the topic and questions of research project that are relevant to them and their daily lives (Wang \& Burris, 1997; Wang, 1999). The key component of reflection after every stage of a research and teaching process can be the points of transformation for all participants (Freire, 1970).

The understanding of the scholar's role as an organizer requires strong interpersonal and political skills to establish positive and trusting relationships with the community and an understanding on the part of the academic as to how to move the formulation of a problem through a process that is conducive to collective research and collective social action, thus "bringing forth the leadership potential in the community" (Park, 1993, p. 10). The design and methods of participatory research also necessitate "demystifying" research methodology by validating the organic, popular means of research to the participants, both students and community members, and the organic language by which data is gathered (Appio, Bartini, \& Smith, 2012). Consequently, dialoguing between "researcher," "community researchers/ participants," (in this case my students), and the community in which the research is conducted, proves integral to the participatory research projects that aim to create positive social change (Maguire, 1987; Ellsworth, 1989; Fals-Borda, 1991; Chan, 1996; Cochran et al., 2008). That communal unity is expressed in the oral and written histories often collected in the research process that forms a collective memory and identity. (Appio, Bartini, \& Smith, 2012). Park (1993) states:

The products of participatory research not only provide people with the technical ammunition for improving their material conditions and for engaging in political struggles, but also supply the grist for their reflection mill... To this end, they must exercise, in dialogue with one another, their collective ability to draw causal inferences for strategic actions and to contemplate the social ramifications that ensue.... Through this theoretically broadened view they can come to understand the plight of other socially marginalized groups as stemming from the same structural source. This understanding paves the way for horizontal coalitions with other communities and groups in struggle and highlights the necessity for linking one participatory research effort with another ( $\mathrm{p}$. $15)$.

Virtually nothing has been written about using a CBPR approach in Vietnamese American communities beyond clinical trials in cancer prevention studies, which have proven to be highly successful and empowering for both community partners and the participants (Lam et al., 2003; Nguyen et al., 2006; Nguyen et al., 2009). The CBPR approach also has been successful in other immigrant and Indigenous communities within the field of public health (Kim, Koniak-Griffin, \& Flaskerud., 2004; Viswanathan et al., 2004; Kim, Flaskerud, KoniakGriffin, \& Dixon, 2005; Cochran et al., 2008; Baumann, Domenech Rodriguez, \& ParraCardona, 2011; Richards, \& Mousseau, 2012). I apply these approaches in my work as an educator, and I believe that they can be transformative in addressing a new generation of 
Vietnamese American students and replicated beyond this ethnic population. In order to meet the changing world environment and learning styles of millennial students, I advocate for an integration of the local and global in pedagogical practice that reflects the transnational and multi-lingual realities of students and local communities. In attempting to do so, my courses try to leverage student access to local neighborhoods in which they reside to develop relevant curricula and research that benefits these communities.

\section{Insider-Outsider Dynamics}

I moved to this geographic area specifically for my position at the university, and I was hired for my specialization in Vietnamese American Studies. Having lived in many different cities and countries throughout my life, my assumption was that entry into the Vietnamese American community in this city would be gradual but relatively easy. This proved to be a more complicated, nuanced relationship. My research and pedagogical practice in the community has thus forced me to reflect on my positionality as a co-ethnic scholar and educator. Anthropologist Renato Rosaldo (1993) describes the traditional modes of ethnography:

According to ethnographies written in the classic mode, the detached observer epitomizes neutrality and impartiality. This detachment is said to produces objectivity because social reality comes into focus only if one stands at a certain distance. When one stands too close, the ethnographic lens supposedly blurs its human subjects. In this view, the researcher must remove observer bias by becoming the emotional, cognitive, and moral equivalent of a blank slate. (p. 168)

He critiques the classic model and makes a critical intervention in ethnographic methods by posing questions that de-mask the role of the researcher: "In discussing forms of social knowledge, both of the analysts and of human actors, one must consider their social positions. What are the complexities of the speaker's social identity? What life experiences have shaped it? Does the person speak from a position of relative dominance or relative subordination?" (p. 169). Moreover, the role of a co-ethnic investigator becomes even more complicated in the dialogical relationship with the community in which they conduct their research. For many, there are expectations as an "insider" within the community, particularly attached to gender and generational roles, to still perform the social customs and norms of one's position in the community via communication, behavior, cultural and political attitude, as well as in the research design and outcomes (Chavez, 2005). Naheed Islam (2000) gives insight into her attempt to research the Bengladeshi American community in Los Angeles:

The essentialized categories of nationality and ethnicity mask the complexities of 'community' and its transnational boundaries. We are not automatically considered insiders in our respective ethnic communities. And both insider and outsider status hold specific meaning and consequences.... as an insider I also faced specific sites of hostility and dilemmas because of my class, gender position, the questions I asked, and the research product I have presented to the 'outside' world. (p. 42)

As a Vietnamese American scholar working within a co-ethnic community that I am unfamiliar with, both as a researcher and an educator, I have experienced similar expectations. Yet, the institutional history of my university and academic unit have both offered me leverage and 
hindered my progress in this trust-building process. My academic unit consists of faculty and staff who have had long-standing relationships in Asian American communities locally-in fact, they played critical roles at times in community development over the past forty years. In addition, my title as a tenure-track professor gave me authority and access in a way that I did not have previously as a graduate student researcher. Upon arrival, I was immediately invited to community events, and very soon thereafter, even invited to sit on boards of organizations that I had very little knowledge of at the time. This became particularly resonant in the interactions with the elementary school as a community partner. Not only was I accepted without hesitation, but because the majority of the SEI teachers were alumni or had some previous relationship with my university and my program, they entrusted me with creating the entire program without challenging me or feeling the need to actively participate in the process (Dao, 2013). The realization that the teachers were completely overwhelmed by their own responsibilities, I felt I could not ask them to provide more time and resources than they were offering. While I appreciated the inherent bond they felt toward me, it also created a dilemma in my understanding of a CBPR process, whereby the community partner would be an equal and engaged partner in the identification and development of a need and the response to it. I also realized I had made assumptions about their previous modes of working with my institution. I had to dismantle my pre-conceived generalizations about the cohesions and collective working styles of the teachers with one another and with me. I had to face the reality of my idealized process - of what the community partner expects from the academic and what constraints they face as individuals or organizations. Over time, I had to gradually form my own terms and methods of collaboration with the school and each individual teacher.

\section{Findings}

\section{Listening, Learning, Validating}

I approached my Vietnamese American Studies course with three main goals: 1) To introduce history, topics, and resources in Vietnamese American Studies, 2) To emphasize the dynamic cultural, economic, political, and sociological changes among people of Vietnamese descent transnationally and globally, and 3) To encourage organic knowledge and cultural production by students who identify as Vietnamese American based on original research and their own lived experiences. This first semester consisted of 12 students, two-thirds of whom were women, and 10 identified as Vietnamese-American, one as Vietnamese, and one as Chinese. I introduced various academic concepts throughout the semester, such as generational and gender role reversals, resettlement policy, anti-communism and reunification, Post-Traumatic Stress Disorder (PTSD), remittances and return, and intersectional identities within the Vietnamese American community. However, students were asked to make short presentations and participate in various assignments and class activities that integrated their personal experiences with their course materials. By the end of the semester, they had to create an individual project of their choice: an oral history of a person from a different generation, a questionnaire to their peers, an annotated bibliography of current research about Vietnamese American communities (such as cancer disparities, political participation, educational achievement, etc.), or an art project that incorporated at least one major theme of the course. The projects were highly personal and involved multi-media presentations of oral histories, detailed art projects using clay, acrylic paints, and other materials, and questionnaire responses from second-generation youth about 
Vietnamese American identity presented in the form of a video diary. While the students expressed great interest in the content, the comfort level with which they situated their own identity formation in varied greatly. In class discussions, I noticed a pattern of stories about their youth that demonstrated the social pressure they felt to conform to mainstream "American" society. One student's example is particularly poignant. While in high school, Diem noticed a critical mass of Asian American students at her school due to the increasing migration from Boston proper. She attempted to start an Asian American student organization but was swiftly rejected by school administrators, who instead claimed her idea was "racist" and convinced her to join Junior ROTC as an alternative (Dao, 2011). Stories like Diem's made me realize that many students I interacted with both longed for and had been conditioned to avoid or even repress their bicultural and ethnic identity formation, and by extension their families and communities, at critical points in their life cycle. One student commented in their evaluation, "This class allowed me to express myself without any boundaries" (Dao, 2011). I considered it a marker of success when at the end of the semester, a group of students from this course, led by Diem, felt motivated to spend their winter holiday creating a proposal and bylaws to re-activate the Vietnamese Student Association (VSA) on campus. For the first time in several years, this student group not only served as a social space for students in the class, but it became the organizing body for events that promoted Vietnamese American culture, identity, discussions, and horizontal alliances across student groups on campus. Today, it remains one of the most active student organizations on campus as its membership has increased multi-fold since its inception. Diem has since graduated but continues to mentor the current leadership and graduated with a decision to go into non-profit work in the Vietnamese American community (Dao, fieldnotes 2014). This first year of teaching at a new institution necessitated that I listen and learn from the students in order to gauge their unique experiences within their local environment. In this process, they became my teachers, and I reciprocated by offering them tools, resources, opportunities, and validation to be reflexive and find value in the classroom for their identity, their lives, and their communities.

\section{Testing Boundaries}

In my second year teaching the course, two-thirds of the students were men, one was a veteran, three-fourths identified as Vietnamese American or Vietnamese Chinese American, one student as African American, one student as Chinese, and all had taken an Asian American Studies course prior to this. It became obvious to me within the first few weeks of the semester that the class seemed to want me not necessarily to teach in traditional modes, but to take the responsibility for their internal journeys, as the majority had some familiarity with what "Asian American Studies courses are about" (Dao, 2012). Because of my assessment about their resistance to engaging in internal self-reflection but their readiness to take on leadership roles, I decided to challenge them to take ownership of their educational experience and lead a community engagement project. Students were asked to use their own personal experiences and to collectively lead the direction of course topics, assignments, and discussions. The class also spent the semester incrementally learning through applied practice an introduction to survey design, creation, implementation, and analysis. They created an assessment questionnaire of Vietnamese living in Dorchester. According to members of the Board of Directors of the local Vietnamese American community center, the Vietnamese American community's needs had not been assessed in over ten years. Again, many of the students felt linguistically and culturally 
marginalized from their ethnic heritage and communities, and thus insecure about interacting with community members beyond their immediate friends and family (Dao, 2012). Yet, using the snowball sampling technique, whereby they leveraged their personal social networks to identify participants, they surveyed over 100 Vietnamese and Vietnamese Americans between 18-86 years of age residing in this Vietnamese enclave of Boston, to ask them about their migration experiences, their sense of "home," their choice to live in this enclave, and what they felt were the current needs of the community. The students created their own themes and questions, categorized and revised the questions, piloted the instrument, implemented the instrument, calculated results, analyzed them, made a video of their findings, and collectively wrote a report of their process and results. Questionnaire results found that while, consistent with popular presumptions, that residents felt there needed to be improvements in safety, schools, and local job opportunities, many also reported feeling "safe" in their neighborhood because a) They could speak Vietnamese and saw other Vietnamese on the streets, b) They knew their co-ethnic neighbors and could depend on them, and c) It was easy for them to go to the co-ethnic stores and businesses in the neighborhood to purchase goods, get assistance, and get information from others (ASAMST 294 Dorchester Community Survey, 2012). While the survey was a worthwhile project that engaged students with their own social networks within the community, the lack of a clear community partner created challenges in recruitment and the lack of longevity for the project past the semester.

\section{Institutional Support and Validation}

During these first few years, the university was shifting in two critical ways. It decisively had the goal to transition into a research-intensive institution, and yet, it was simultaneously committed to retaining its urban mission in several key ways, including maintaining its reputation as a community engaged institution by forming an Office of Community Partnerships (OCP). The OCP documented existing and identified new campus-community partnerships that could be fostered. Its activities included offering a) professional development and CBPR training series over the course of three semesters, and b) funding sources that helped build these collaborative projects. Faculty in the Asian American Studies Program, including myself, were selected to participate in this professional development training and grant to create a partnership project with Hope Elementary that included a special topics course.

In the spring of 2014, I taught the grant initiated special topics sequence. The course represented the next stage in fulfilling my goal to use CBPR in my teaching. With the small grant from the OCP, I was able to create a project-based course with compensation for two Hope SEI teachers to be advisors. The idea for this course began when I accompanied another Asian American Studies class to an SEI $2^{\text {nd }}$ grade class during a visitation day. These visitation days were an opportunity for parents to bring food to class and listen to their children read the stories they had written for class in English. On this day, one mother whispered to me, "I love these opportunities to come to class because it gives me a chance to learn English, too. I learn what he learns" (Dao, 2013). After class, I spoke with the teacher, who told me that many of the parents had the desire to learn English as well but did not have the resources to pay for English classes. The teacher took it upon herself to begin teaching the parents one evening a week for free. Unfortunately, she feared she would be unable to continue the course this academic year (Ibid). Finally, at the end of their academic year, I and another colleague teaching the Asian American Studies internship course, organized a formal meeting with all the Vietnamese SEI teachers to 
identify the needs of the teachers and where our students/courses might support them. These observations, informal, and formal conversations gave rise to the organic emergence of the collaborative problem-solving process with the community partner that I then matched with the discussions and conversations with students about their desires to volunteer in the community while learning about their ethnic identities (Dao, 2011-2013).

\section{Contributing to SEI Curricular Materials}

In Spring 2014, students recruited for this pilot course used their bilingual Vietnamese-English skills to work closely with parents of the children in the elementary school to add another dimension to the existing campus-community partnership through Asian American Studies, whose alumni include four of the SEI teachers. The students in my course visited the classroom three times that semester, the first two times to be oriented in the classroom experience and see what materials they currently had, and the end of the semester to share their completed bilingual storybooks with the students. One student commented during the debrief of the visit, "Some of the students reminded me of myself when I just arrived in the U.S. a few years ago. I was so scared and shy" (Dao, 2014).

The students conducted oral history interviews with alumni of our school's Asian American Studies Program and the elementary school's SEI program. Then they collectively transcribed, coded, and analyzed the interviews. One student reflected on her opportunity to build inter-generational relations with an alumna:

Coming into the interview, I felt ready. As I got there, I went blank because of the fact that I was so nervous. I felt very self-conscious that I was going to do something wrong. But I soon realized that I should have just gone with the flow. When I introduced myself, I realized that my interviewee was much older than me, so it did feel uncomfortable at first. On the other hand, because of this interview, I was able to get used to interviewing people that aren't my age. I also soon felt comfortable when we talked about our similar taste in majors. Once the interview started I realized we had a lot of similarities. Especially when I asked questions about her family. One question that I thought that was related was the fact that her family and my family had similar backgrounds when it came to the topic of coming to the United States ("Cat" reflection, spring 2014).

Another student bonded with the alumnae's family experiences:

Sometimes, I saw Linh [pseudonym] almost tearing up about her past but she did not afraid to share it with me. This made me feel extremely privilege to be part of the conversation. She told me how her parents want her to pursue certain career and she did everything she could to achieve that. It reminded me about my family situation too. ("Truc" reflection, spring 2014).

These interviews served as a foundational step to creating storyboards for bilingual storybooks. An Asian American Studies alumnae and current graduate student who substituted at the elementary school conducted storyboarding workshops with the students and individually mentored them in the storybook process. The topics students covered in the stories dealt with Vietnamese American child protagonists who had to overcome a conflict she or he had at school 
or with his/her family at home, usually relating to adjusting to a new environment and not understanding the language or having friends. One student wrote:

An idea that just came to my mind was to create a story based on that incident on the bus. Quyen [pseudonym] talks about certain students on the bus and their role such as the caregiver, the family friend, etc. The situation that Quyen is facing is that she does not have a role in her classroom. But when the new student that has just recently immigrated to Vietnam was on the school bus, situations such as the teacher saying "Speak English!" would occur. At that time, Quyen realizes that her role is to be someone that would protect those who do not have a voice. ("Hang" reflection, 2014)

Quyen's story became a story about a young Vietnamese American "superhero" classmate. Hope Elementary alumna "Tram" decided to interview her former SEI teacher, and found to her amazement that she knew nothing about her, but "Co Nhi's [pseudonym] stories brought me to tears but because I was interviewing her I tried really hard not to cry. I am so glad to do this project, especially with her. When I was in the class with Co Nhi in elementary school I did not know the challenges that she went through" ("Tram" reflection, 2014). Her interview evolved into a story about a little girl who just immigrated from Viet Nam and was late to school because of she got lost on the bus system but was too afraid to tell her teacher, Lan's First Day of School. Luckily, the teacher in the story was kind and empathetic and did not reprimand the little girl, thus showing the challenges, fear, and desire of newly immigrated students to be understood. Another student created a compelling story based on his own feelings of isolation as a new child immigrant, which he felt were validated by his interviewee:

As a college student and I only immigrant to the America for around 3 years, I feel like her story 20 years ago in SEI class similar to me. She was put in the class with a lot of immigrant people even she was born here. Later on, she understand that her mother put her into the class because her mother wanted she to understand the Vietnamese culture, history, and have the Vietnamese environment on her. She embraces Vietnamese culture; heritage and more appreciate to be in the class. I have different background from her but I can understand how hard she has to adopt with new environment, with people speaking language that is not her first language. I could easily see it through my experience here when I first went to school in the United States. I was nervous, felt alone but always tried my best to adopt and get better in my career. I was put in SEI classes and those classes help me a lot when I have friends and teachers help me with my English. Those people have a lot of impact on me because they are the foundation of my career and succeed after my college life. My impression about her is she remembers all the names of her Vietnamese teacher in Mather school. She also remembers some of the kids in her class even that was 20 years ago. This mean the SEI program on Mather school had a lot of impact on her. Teachers and friends have huge effect on her background, culture. ("Hung", 2014)

These stories attempt to fill the gaps in children's literature readily available to Asian and Asian American students at the elementary school, thus offering students characters with whom they can identify. The students in my class reported a sense of collective identification with the alumni they interviewed, from whom they saw a path for their future aspirations. Additionally, they shared a deep sense of empathy with the students at Hope Elementary and felt a sense of 
accomplishment in bridging the stories of alumni, of adding to bilingual curricular materials, and, especially, of being able to have tangible, meaningful products at the end of the semester that they could personally share with the students. The reflection process, which included postsession debriefs over dinner, weekly reflection papers, and a final paper provides the roadmap for how to approach the course in the future. At the end of the semester, parents and UMB students visited the classroom, where they had the opportunity to read the stories to the SEI students in both English and Vietnamese. Hard cover copies of the bilingual storybooks were then gifted to the SEI class. The storybook project exemplifies how the meaning-making process could be relevant, rewarding, and academically rigorous (in teaching methodology), to students and community partners alike.

\section{Building Cyclical Communities}

The interest and relationships built during the spring semester led directly to the continuation of the program in the fall through my Vietnamese American Studies course. That spring 2014 semester, the Asian American Studies internship course also placed a student in one SEI classroom, during which time, she felt compelled to provide additional tutoring to struggling students from this class by creating a Saturday tutoring program at the local public library. Serendipitously, one student from the spring special topics course also wanted to continue with her involvement with the elementary school. This gave way to an opportunity for cascading mentorship between the senior and the freshman students. The senior mentored the freshman on developing tutoring curriculum and facilitating sessions. Once again, we worked with the same SEI teacher to identify students needing extra support, and the student was hired as a work-study to assist the teacher for three hours a week at Hope Elementary to gain insight on the students' development in school. Students in my Vietnamese American Studies course were then given the Saturday Sessions tutoring program, called Saturday Sessions, as an option for their final projects, for which they had to commit two hours a week throughout the semester (twelve weeks total) to the program, write weekly reflections, and write a final programmatic reflection at the end of the semester (Dao, 2014). Seven students of the twelve participated in Saturday Sessions. Below is an example of the Saturday Session activity:

This week we started off with introducing ourselves and telling everyone our favorite Vietnamese dish. And we played an ice breaker game with the kids to get them feeling a little comfortable. We then were assigned our own student and we read "The Lion and the Mouse," it was a fictional and fantasy story. We then got back into a big circle and role play each character, and the little students was assigned to write about what they liked about the session and they had to describe when a time they felt like the mouse in the story. ("Tam" reflection, 2014)

While Saturday Sessions focused on providing additional English language tutoring for Hope Elementary students, it also became a way to develop mentor-mentee relationships as the program would have assigned one-on-one tutoring but also have fun group activities for all the college and elementary students to bond together. These opportunities opened the door for the children to share their personal lives, fears, and perspectives with their mentors. Finally, mentors began to reflect on their own leadership, mentorship, and teaching styles and how to improve them, as one student shared: 
My mentee would talk about his family and his personal life, what his favorite hobbies were, and his favorite food. He also randomly mentioned his dog in Vietnam had died a while back before he came to America. The only support I would need is how discipline my mentee without sounding like an asshole. Sometimes I can get to that point without realizing it. My mentee is really hyper all the time and it can be a struggle to get him to settle down. ("Thanh" reflection, fall 2014)

The reflections and debriefing meetings also provided me the opportunity to hear from the mentors what challenges they were having with students, and when concerns should be raised with their Hope Elementary teacher. I also had the chance to speak with some of the mothers who dropped off their children on my occasional observations of the program. At this time, the parents talked with me about their own concerns with their child, such as whether Thanh's mentee in the quote above needed to be tested for ADHD. The Saturday Sessions thus provided holistic mentoring, particularly for students who did not have older siblings or know anyone in college, a chance for students to provide peer support and bond outside of school, as many mentioned they usually were left at home on the weekends while their parents worked, and an opportunity for mentors and myself to further make observations about student behavior and progress to support the Hope Elementary teacher. This program deepened the students' one-onone mentoring relationship with the elementary students, and thus their understanding of the daily lives and mentoring needs of the students. Moreover, because there was a peer facilitator, I removed myself from the immediate space, only visiting sporadically after the first month of the semester. My interventions and advising came instead in the form of facilitating oral debriefs in class, responding to student reflections, and giving the peer facilitator feedback on lessons plans in their developmental stage. This forced students to depend on one another for peer support and collective problem-solving. The challenge and disappointment of this program was its sustainability, which had to be adjusted the next semester.

\section{Fits and Starts in Forging New Ground}

By the end of the semester, five students from the course approached me with interest in continuing their relationship with the SEI classes. Given the challenges of the Saturday schedule, however, for the students who had to work on the weekends, we devised an independent study course that integrated students into the SEI classrooms during the week this semester. Each student is matched with an SEI teacher to assist in the classroom three hours a week, write weekly reflections, meet biweekly as a class to reflect, compare experiences, and collectively problem-solve, and create a final product that will further support the teacher. Each teacher is also asked to provide monthly evaluations of the student assistants to improve their participation in the classroom and potentially provide a model for future internships at the school. The process by which I took to achieve a deeper and more integrated relationship with multiple SEI teachers and the school as a whole has been a slow but steady development that required negotiations, adjustments, and flexibility in my vision for my courses each semester. The collective of goal of the students is to move the tutoring program and the annual university campus visit in May that was started by the students in spring 2014 into the VSA as a summer program, and have it be retained as a course-credit internship for the school year. 


\section{Future Directions in Pedagogical Pathways}

As a new faculty member in a new campus and community environment, it has been a slow process for me to evolve from a more traditional mode of teaching and learning to a CBPR approach to Vietnamese American Studies. The student population that I work with justified to me a Freiran model of education based on popular education principles outlined in my theoretical framework as well as the co-creation of CBPR projects that validated their ethnic identities and organic knowledge. I recognize that my use of these principles still had to be mitigated within the classroom space, in that I had to play a directing role with the vision and direction of the course, forge the institutional relationships with community partners, and identify learning outcomes in research and theory that were acceptable to university standards. Yet, I feel that these principles significantly impacted my approach to working in this learning community such that students gained insight into their community and themselves in the process of learning academic skills in a way that had currency to them. Significantly, this approach and these projects could not have been possible without the support of my academic unit and institution, which have explicitly valued and promoted such pedagogies and methodologies. In fact, my particular program gave me "insider" access, along with my assumed shared values as a coethnic scholar, that often take people years to develop. I also had to make the conscious choice not to reproduce the expectations of me in the community based on my intersectional identities and access to resources through the university. Simultaneously, I had to be careful not to be overly dependent and presumptuous on the trust, relationship, and modes of collaboration that already existed between the program and the community partner and Vietnamese American students.

While there have been fits and starts to the process of identifying the best approach, the process of experimentation and reflection through observation and listening have played a major role in my curricular development. As I embark on the journey of learning to be Vietnamese Americanist in the $21^{\text {st }}$ Century, I am still building a relationship of trust and reciprocity with the

community partner that allows for open communication and collective development of more integrated projects while navigating my own boundaries and contributions that are often expected from one's co-ethnic community. With my students and this community, we will "make the road by walking" (Horton \& Friere, 1990).

\section{References}

Appio, L. M., Bratini, L., \& Smith, L. (2012). Everybody's teaching and everybody's learning: photovoice and youth counseling. Journal of Counseling and Development, 90(1), 3-12.

Arnold, R. \& Burke, B. (1983). A popular education handbook. Toronto: Ontario Institute for Studies in Education.

Boat People S.O.S. (BPSOS). (2012). The Vietnamese population in the United States: 2010. Washington, D.C.: BPSOS.

Boston Redevelopment Authority (BRA). (October 2012). New Bostonians 2012. Retrieved from http://www.bostonredevelopmentauthority.org/getattachment/038e3963-7217-47e3-9795c679d65ab498/ 
Baumann, A., Domenech-Rodriguez, M., \& Parra-Cardona, J.R. (2011). Community-based applied research with Latino immigrant families: Informing practice and research according to ethical and social justice principles. Family Process, 50(2), 132-148.

Chan, L. H. (1996). Talking pain: Educational work with factory women in Malaysia. In S. Walters \& L. Manicom (Eds.) Gender in popular education: Methods for empowerment (pp. 202-228). London, UK: Zed Books.

Charmaz, K. (2006). Constructing grounded theory: A pracitcal guide through qualitative analysis. Thousand Oaks, CA: Sage Publications.

Chavez, C. (2005). Conceptualizing from the inside: Advantages, complications, and demands on insider positionality. The Qualitative Report, 13 (3), 474-494.

Chung, C. H. (1999). Vietnamese-American students: Between the pressure to succeed and the pressure to change. In C. C. Park \& M. MY. Chi (Eds.), Asian-American Education: Prospects and Challenges (pp. 183-200). Westport, CN: Bergin \& Garvey.

Cochran, P. A. L., Marshall, C. A., Garcia-Downing, C., Kendall, E., Cook, D., McCubbin, L. (2008). Indigenous ways of knowing: Implications for participatory research and community. American Journal of Public Health, 98(1), 22-27.

Dao, L. (Fall 2011-Spring 2013). Course evaluations.

Dao, L. (Fall 2012). ASAMST 294 Dorchester community survey. Unpublished.

Dao, L. (March 20, 2013). Fieldnotes for CESI course observation.

Dao, L. (August 1, 2013-December, 20, 2014). Monthly fieldnotes for course projects.

Dewey, J. (1997). Experience and education. New York, NY: Touchstone (reprint).

Ellsworth, E. (Sept.1989). Why doesn't this feel empowering? Working through the repressive myths of critical pedagogy. Harvard Educational Review, 59(3), 297-325.

Freire, P. (1970). Pedagogy of the oppressed. (2nd ed.) New York, NY: Continuum.

Hall, B. (1978). Continuity in adult education and political struggle. Convergence. XI(1), 8-15.

Hall, B. (1982). Breaking the monopoly of knowledge: Research methods, participation, and development, In B. Hall, A. Gillette, \& R. Tandon (Eds.). Creating knowledge: A monopoly? Participatory research in development. Toronto, CAN: Society for Participatory Research in Asia.

Hope Elementary School. (2014-2015). Vietnamese Sheltered English Immersion (SEI) enrollment and meal assistance summary. Personal correspondence with Hope Elementary School.

Fals-Borda, O. (1991). Remaking knowledge. In O. Fals-Borda \& M. A. Rahman (Eds.), Action and knowledge: Breaking the monopoly with participatory action research (pp. 146-166). New York, NY: Apex.

Glasser, B. G., \& Strauss, A. L. (1967). The discovery of grounded theory. Chicago, IL: Aldine.

Horton, M., \& Friere, P. (1990). We make the road by walking: Conversations on education and social change. Philadelphia, PA: Temple University Press.

Islam, N. (2000). Research as an act of betrayal: Researching race in an Asian community in Los Angeles. In F. W. Twine \& J. W. Warren (Eds.), Racing research researching race: Methodological dilemmas in critical race studies (pp. 35-66). New York, NY: New York University Press.

Israel, B. A., Schulz A. J., \& Parker E. A. (1998). Review of community-based research: assessing partnership approaches to improve public health. Annual Review of Public Health, 19,173-202.

Israel, B. A., Schulz, A. J., Parker, E. A., Becker, A. B., Allen, A. J., \& Guzman, J. R. (2003). 
Critical issues in developing and following participatory research principles. In M. Minkler \& N. Wallerstein (Eds.), Community based participatory research for health (pp. 53-76). San Francisco, CA: Jossey-Bass.

Kiang, P. N. (March 2006). Policy challenges for Asian American and Pacific Islanders in education. Race Ethnicity and Education, 9 (1), 103-115. DOI: $10.1080 / 13613320500490838$

Kim, S., Flaskerud, J. H., Koniak-Griffin, D., \& Dixon, E. L. (2005). Using communitypartnered participatory research to address health disparities in a Latino community. Journal of Professional Nursing, 21(4), 199-209.

Kim S., Koniak-Griffin D., Flaskerud J. H. (2004). The impact of lay health advisors on cardiovascular health promotion: using a community-based participatory approach. Journal of Cardiovascular Nursing, 19(3), 192-199.

Lam, T. K., McPhee, S. J., Mock, J., Wong, C., Doan, H. T., Nguyen, T., ... Luong, T.N. (2003). Encouraging Vietnamese-American women to obtain pap tests through lay health worker outreach and media education. Journal of General Internal Medicine, 18(7), 516-524. DOI: 10.1046/j.1525-1497.2003.21043.x

Lo, S., \& Tran, T. (August, 2012). Profiles of Asian American subgroups in Massachusetts: Vietnamese Americans in Massachusetts. Boston, MA: Institute for Asian American Studies.

Maguire, P. (1987). Doing Participatory Research: A Feminist Approach. Amherst, MA: Center for International Education.

Minkler, M. (2005). Community-Based Research Partnerships: Challenges and opportunities. Journal of Urban Health: Bulletin of the New York Academy of Medicine, 82 (2.2), ii3i12.

Minkler, M., \& Wallerstein, N. (2008). Community-based participatory research for health: From process to outcomes. (2nd ed.) San Francisco, CA: Jossey-Bass.

Nguyen, T. T., Le, G., Nguyen, T., Le, K., Lai, K., Gildengorin, G., McPhee, S. J. (2009). Breast cancer screening among Vietnamese Americans: A randomized controlled trial of lay health worker outreach. American Journal of Preventive Medicine, 37(4), 306-313. doi:10.1016/j.amepre.2009.06.009

Nguyen T. T., McPhee S. J., Bui-Tong N., Luong T.-N., Ha-Iaconis T., Nguyen T., Wong C.,...Lam H. (2006). Community-based participatory research increases cervical cancer screening among Vietnamese-Americans, Journal of Health Care for the Poor and Underserved, 17, 31-54.

Office of Institutional Research at University of Massachusetts Boston. (2012-2014). Student Characteristics Profile. $\quad$ Retrieved from $<$ http://www.umb.edu/oirp/student_characteristics $>$

Park, P. (1993). What is participatory research? A theoretical and methodological perspective. In P. Park, M. Brydon-Miller, B. Hall, and T. Jackson (Eds.), Voices of change: Participatory research in the United States and Canada (pp. 1-20). Westport, CN: Bergin \& Garvey.

Richards, J., \& Mousseau, A. (2012). Community-based participatory research to improve preconception health among Northern Plains American Indian adolescent women. American Indian and Alaska Native Mental Health Research: The Journal of the National Center, 19(1), 154-185.

Rosaldo, R. (1989). Culture and truth: The remaking of social analysis. Boston, MA: Beacon Press. 
Saltmarsh, J., \& Zlotkowski, E. (Eds.). (2011). Higher education and democracy: Essays on service-learning and civic engagement. Philadelphia, PA: Temple University Press. Retrieved from http://www.ebrary.com

Saltmarsh, J., \& Zoltkowski, E. (April 14, 2010). Students as colleagues in the next generation of civic engagement. New England Regional Campus Compact Meeting.

Southeast Asian Resource Action Center (SEARAC). (Oct. 06, 2011). Southeast Asian Americans at a glance: Statistics on Southeast Asians adapted from the American Community Survey. Washington, D.C.: SEARAC.

Strauss, A., \& Corbin, J. (1998). Basics of qualitative research: Grounded theory procedures and techniques. (2nd ed.) Thousand Oaks, CA: Sage Publications.

Strauss, A., \& Corbin, J. (1990). Basics of qualitative research: Grounded theory procedures and techniques. Newbury Park, CA: Sage Publications.

Tung, R., Diez, V., Gagnon, L., Uriarte, M., Stazesky, P., de los Reyes, E., \& Bolomey, A. (2011). Learning from consistently high performing and improving schools for English Language Learners (ELL) in Boston public schools. Boston, MA: Gastón Institute Publications.

Uriarte, M. \& Karp, F. (2009). Enrollment and academic outcomes of English Language Learners (ELL) in Pre-K to Grade 3 in Boston public schools. Boston, MA: Gastón Institute Publications.

Uriarte, M., Lavan, N., Agusti, N., Kala, M., Karp, F., Kiang, P.N., Lo, L., Tung, R., \& Villari, C. (2009). English learners in Boston public schools: Enrollment, engagement, and academic outcomes of native speakers of Cape Verdean creole, Chinese dialects, Hiatian creole, Spanish, and Vietnamese. Boston, MA: Gastón Institute Publications.

Viswanathan, M., Ammerman, A., \& Eng, E. (2004). Community-based participatory research: Assessing the evidence. (AHRQ Pub. No. 04-E022-2.) Rockville, MD: Agency for Healthcare Research and Quality.

Wang, C. (1999). Photovoice: A participatory action research strategy applied to women's health. Journal of Women's Health, 8, 185-192.

Wang, C., \& Burris, M. A. (1997). Photovoice: Concept, methodology, and use for participatory needs assessment. Health Education and Behavior, 24, 369-387. 


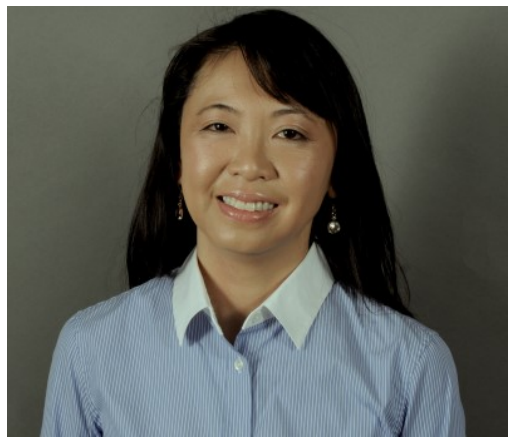

Loan Dao is an Assistant Professor in the undergraduate Asian American Studies program and the graduate Transnational Cultural and Community Studies program at the University of Massachusetts Boston. She received her Ph.D. at the University of California, Berkeley, in Comparative Ethnic Studies, and specializes in Southeast Asian refugee migration and community development, immigrant and refugee youth, social movements, and Community-Based Participatory Research (CBPR). Her research has included media representations of Southeast Asian American youth, health disparities in Vietnamese American populations, leadership development for Vietnamese and Vietnamese American female students, Vietnamese musical theater, and memory and the Viet Nam War through popular culture and exhibits. Her current project examines the experiences of Asian American youth and Southeast Asian American youth organizing in the immigrant rights movement. 


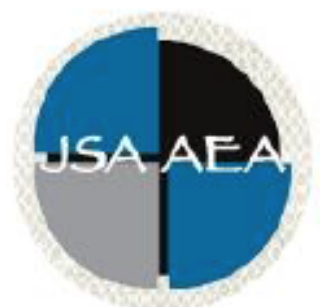

Vol. 10 Iss. 2 Special Issue (2015)

\section{Journal of Southeast Asian American}

Education and Advancement

www.JSAAEA.org

\section{Special Issue Editors}

Vichet Chhuon

University of Minnesota

anthony lising antonio

Stanford University

\section{Editor}

Dr. Wayne E. Wright

Purdue University

\section{Associate Editors}

Dr. Chhany Sak-Humphry

University of Hawaii at Manoa

Dr. Phitsamay Sychitkokhong Uy University of Massachusetts, Lowell

\section{Book Review Editor}

Dr. Vichet Chhuon

University of Minnesota

\section{Creative Works Editor}

Bryan Thao Worra

Lao Assistance Center

\section{Journal Manager}

Marshall Klassen

Purdue University

\section{Editorial Review Board}

Dr. Steve Arounsack

California State University, Stanislaus

Dr. Sovicheth Boun

The State University of New York at Fredonia

Dr. George Chigas

University of Massachusetts, Lowell

Dr. Hien Duc Do

San Jose State University

Dr. Sophal Ear

Occidental College
Dr. Carl L. Bankston III

Tulane University

Dr. Phala Chea

Lowell Public Schools

Dr. Loan Dao

University of Massachusetts, Boston

Dr. Changming Duan

University of Missouri, Kansas City

Dr. Sothy Eng

Lehigh University 
Dr. Jeremy Hein

University of Wisconsin, Eau Claire

Dr. Nancy H. Hornberger

University of Pennsylvania

Dr. Peter Nien-Chu Kiang

University of Massachusetts, Boston

Dr. Ha Lam

Arizona State University

Dr. Jonathan H. X. Lee

San Francisco State University

Dr. Monirith Ly

Royal University of Phnom Penh

Dr. Bic Ngo

University of Minnesota

Dr. Leakhena Nou

California State University, Long Beach

Dr. Mark Pfeifer

SUNY Institute of Technology

Dr. Loan T. Phan

University of New Hampshire

Dr. Kalyani Rai

University of Wisconsin, Milwaukee

Dr. Cathy J. Schlund-Vials

University of Connecticut, Storrs

Dr. Nancy J. Smith-Hefner

Boston University

Dr. Yer J. Thao

Portland State University

Dr. Monica M. Trieu

Purdue University

Dr. Silvy Un

Saint Paul Public Schools

Dr. Terrence G. Wiley

Center for Applied Linguistics

\author{
Dr. Vincent K. Her \\ University of Wisconsin, Eau Claire \\ Dr. Peter Tan Keo \\ New York University \\ Dr. Kevin K. Kumashiro \\ University of San Francisco \\ Dr. Ravy Lao \\ California State University, Los Angeles \\ Dr. Stacey Lee \\ University of Wisconsin, Madison \\ Dr. Sue Needham \\ California State University, Dominguez Hills \\ Dr. Max Niedzwiecki \\ Daylight Consulting Group \\ Dr. Clara Park \\ California State University, Northridge \\ Dr. Giang Pham \\ University of Massachusetts \\ Dr. Karen Quintiliani \\ California State University, Long Beach \\ Dr. Angela Reyes \\ Hunter College, The City University of New York \\ Dr. Fay Shin \\ California State University, Long Beach \\ Dr. Christine Su \\ Ohio University \\ Dr. Alisia Tran \\ Arizona State University \\ Dr. Khatharya Um \\ University of California, Berkeley \\ Dr. Linda Trinh Vo \\ University of California, Irvine \\ Dr. Yang Sao Xiong \\ University of Wisconsin-Madison
}

Dr. Zha Blong Xiong

University of Minnesota

\section{Doctoral Student Editorial Review Board}

\author{
Virak Chan \\ University of Texas at San Antonio \\ Annie BichLoan Duong \\ San Joaquin County Office of Education \\ Hoa Nha Nguyen \\ Boston College \\ Malaphone Phommasa \\ Marshall University
}

\author{
Keo Chea-Young \\ University of Pennsylvania \\ Dung Minh Mao \\ University of Minnesota \\ Thien-Huong Ninh \\ University of Southern California \\ Krissyvan Truong \\ Claremont Graduate University
}


Journal of Southeast Asian American Education and Advancement, Vol. 10 [2015], Iss. 2, Art. 6

Molly Wiebie

The University of Texas at Austin

\section{Soua Xiong}

San Diego State University \&

Claremont Graduate University

Anna H. Yang

University of Georgia

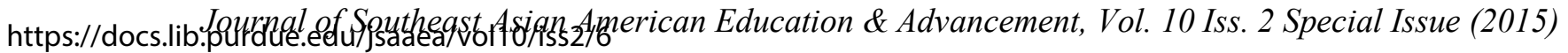

